\title{
ROY RAPPAPORT: RITUAL AND RELIGION IN THE MAKING OF HUMANITY
}

\author{
Hans J. Lundager Jensen
}

Med Roy Rappaports bog Ritual and Religion in the Making of Humanity fra 1999 har religionsvidenskaben fået et værk, der efter min mening allerede kandiderer til status som nyklassiker. Artiklen her erstatter en anmeldelse af bogen med en mere omfattende omtale og præsentation, som dog ikke kan yde denne rige og komplicerede bog fuld retfærdighed. Omtalen vil fremdrage visse hovedlinjer.

Bogen er en sammenskrivning og sammenfatning af en række teoriudkast og empiriske studier, navnlig artiklen "The Obvious Aspects of Ritual” fra 1974, artikelsamlingen Ecology, Meaning, and Religion (1979) og Pigs for the Ancestors: Ritual in the Ecology of a New Guinea People (2. ed. 1984). Rappaport døde i 1997, og bogen er publiceret posthumt, hvad den også bærer spor af. Den virker ikke helt færdig: bestemte vendinger og mindre afsnit gentages rundt omkring på en lidt forvirrende måde, visse problemer har ikke fået den tilslibning, som monografiformatet kunne have tilsagt, osv. Bogen er i øvrigt en lidt mærkelig læseoplevelse. På den ene side er der ofte tale om en tung og besværlig tekst med megen grundighed og mange møjsommelige forklaringer; på den anden side er den sine steder elegant og en fornøjelse at læse. Alt $i$ alt er det en stor og tung bog, der kræver en hel del læsearbejde og tid. Men det er biting.

Ritual and Religion in the Making of Humanity kombinerer forfatterens egne etnografiske iagttagelser og analyser med et imponerende teoriapparat. Dette omfatter: (1) Klassiske synspunkter fra antropologi og religionsvidenskab på ritualer og hellighed; Durkheim er helt grundlæggende her, ${ }^{1}$ men der henvises også til bl.a. Radcliffe-Brown, Otto, James, Eliade og Turner. (2) Peirces semiotik, hvor navnlig forskellen mellem symbolske og indeksikale tegn er relevant. (3) En batesonsk kybernetik og neodarwinisme, med hovedvægt på adaption og på sondringen mellem generelle systemer og specielle sub-systemer. (4) Austins talehandlingsteori, naturligvis med særlig henblik på performative sproghandlinger. (5) Andre, herunder, og uden berøringsangst, hermeneutisk-teologiske overvejelser hos bl.a. Buber og Tillich.

\section{Ritual og religion}

I bogen er ritual og religion to felter, der delvist, men kun delvist, dækker hinanden. Ritualet er det primære, og Rappaport er omhyggelig med sin definition: med ritual skal forstås "udførelsen (performance) af mere eller mindre invariante sekvenser af formali-

\footnotetext{
${ }^{1}$ Keith Harts forord lægger med rette særlig vægt på kontinuiteten tilbage til Durkheims Les Formes élémentaires de la vie religieuse (1912).
} 
serede (formal) handlinger og ytringer, der ikke er fuldstændig kodificerede (encoded) af dem, der udfører dem (the performers)" (s. 24). Ritualer er dermed ikke defineret som specielt religiøse. Grunden til, at en ritualteori også og ikke mindst er en religionsteori, er, at ritualer i praksis igennem historien oftest har været primært religiøse, og at det er i deres religiøse skikkelse, at deres egentlige funktion tydeligst kommer til udtryk.

Rappaport leverer ikke en lignende stringent definition af religion, men går ud fra, at det giver mening at lade den være sammenfattet i 'det Hellige' (the Holy; med understregning af den etymologiske rod i 'hel', 'helhed'), der indbefatter (1) 'det hellige' (the sacred $)^{2}$, dvs. værdier der anses for indiskutable og evige; (2) 'det numinøse', der er individets oplevelse af noget overnaturligt, som fx Ottos begreb om en erfaring af det numinøse; (3) 'det okkulte', der er faktiske effekter, fx 'magiske', af det hellige og det numinøse; (4) 'det guddommelige', der er overnaturlige og oftest usynlige agenter.

Det ritual- og religionsteoretiske udgangspunkt er Robertson Smiths gamle og fundamentale iagttagelse af, at ritualernes ydre handlinger generelt er stabile, mens deltagernes interpretationer er variable. En religiøs gruppes medlemmer gør det samme, selv om de eventuelt tænker forskelligt, dvs. forbinder noget forskelligt med deres handlen; en religionsteori bør derfor begynde med ritualet. Det primære og afgørende ved ritualet ifølge Rappaport er imidlertid ikke, hvad deltagerne gør, endsige hvorfor de gør det, men selve det, at de gør det, dvs. at de deltager. Derved underkaster deltagerne sig en fælles norm, dvs. de forpligter sig på et fælles grundlag (inklusive en fælles 'ideologi', vil jeg sige). Og dette er det afgørende, for uden fælles norm, uanset dennes indhold, intet samfund, intet sprog, ingen gensidig forståelse. Derfor er ritual samfund, og derfor forudsætter samfund ritual.

\section{Løgn og Babel}

Forudsætningen for Rappaports ræsonnement er antagelsen af, at mennesker i modsætning til andre dyr er henvist til selv at danne betydninger (både sproglige betydninger og fx adfærdsnormer), for mennesker har ikke (længere) instinkter, der automatisk fortæller dem, hvordan de skal handle. Dette er adaptivt en fordel, fordi de derfor kan omstille sig meget hurtigt til ændrede livsforhold, hvorimod andre levende arter må omstille sig genetisk, hvilket naturligvis er en uendeligt langsommere proces. Ifølge Rappaport er betydninger oftest 'symbolske' i Peircesk forstand, dvs. at der består et arbitrært forhold mellem udtryk og indhold (jf. det klassiske semiotiske eksempel: hest/cheval/Pferd).

Men da betydninger er rent menneskelige produkter, kommer de ikke kun let, men går lige så let: kulturens to farer er derfor henholdsvis løgn (at der ikke består noget forhold mellem tegn og ting) og forvirring (eller 'Babel': at der består uklarhed om forholdet mellem tegn og ting). For at menneskene kan leve sammen i en gruppe, må der være både basal enighed om betydningerne og plads for ændringer; betydningssystemet (og normative regler, fælles grundantagelser osv.) må være nogenlunde stabilt,

\footnotetext{
${ }^{2}$ The sacred: kan næppe oversættes til dansk med andet end 'det hellige', selv om det dermed vil kunne forveksles med the Holy; i skriftsprog vil man måske kunne klare sig med forskellen mellem store og små bogstaver?
} 
uden at være for fastlåst. Den nødvendige enighed kommer nu ifølge Rappaport i stand ved, at gruppens medlemmer frivilligt underkaster sig et sæt af fælles betydninger og normer. Denne underkastelse sker mest markant og stærkest virkende i ritualet, der er et sæt af fælles handlingsforskrifter, som deltagerne går ind i og underkaster sig. De 'ofrer' så at sige deres individuelle frihed, de aflægger sig mulighederne for og risikoen ved løgn og Babel for at opnå en fælles konsensus. Konsensus om betydningerne kan næppe nogensinde være total og bør heller ikke være det, da den i så fald ville udelukke eller i det mindste urimeligt besværliggøre forandringer; men den skal være tilstrækkeligt omfattende for at kunne fungere som det fælles og indiskutable reservoir af betydning (normer etc.), uden hvilket der ikke ville eksistere nogen gruppe, i hvert fald ikke ret længe.

\section{Betydning og krop}

Ritualet er dette reservoir af betydning, fordi individerne her fysisk og konkret er samlet og er sammen, og fordi handlingsforskrifterne (fælles dans, sang, fremsigelse af formularer, kropslige bevægelser) tendentielt får dem til at fungere som én krop; her knytter Rappaport naturligvis til ved den rituelle effervescens hos Durkheim og RadcliffeBrown. Adspredtheden bliver dermed ikke kun symbolsk, men delvis reelt, til samling; af de mange kroppe (med hver deres perspektiv og erfaringer) bliver der, for en tid, (tendentielt) én fælles krop med ét fælles perspektiv og erfaring. Dansende, syngende, knælende kroppe opgiver dele af deres individualitet, ikke kun formelt, men formentlig også helt konkret og korporligt i og med synkroniseringen af hjerteslagene. Det er ifølge Rappaport afgørende, at denne samling og forening ikke kun symboliseres, men realiseres, kropsliggøres. Derfor kan ritualet nok suppleres med noget andet, fx en fælles doktrin, transmitteret på anden vis, fx ved mundtlig eller skriftlig meddelelse, men ikke erstattes af dette; dermed ville fællesskabet nemlig blive afhængigt af den symbolske kommunikation alene, og den ville da igen være udsat for løgn og Babel. Ritualet i sig selv er ikke et rent humant fænomen; tværtimod findes rituel adfærd også hos dyrearter (Rappaport henviser ikke til Walter Burkert, fx Burkert 1996, hvad han kunne have gjort). Ironisk, men påfaldende nok benyttes en mere 'primitiv', mindre unik human kommunikationsform typisk, når betydninger virkeligt betyder noget, fx ved afgivelse af løfter, aflæggelse af eder, erklæringer om loyalitet, optagelser i grupper osv. De rent humane betydninger, dvs. de, der alene er formuleret i symboler såsom talte ord, er her for 'lette', hvorfor kropsbevægelser må med for at give erklæringerne vægt.

\section{Værdihierarki}

De normer og betydninger, som deltagerne underkaster sig (i realiteten: bekræfter deres underkastelse under) har forskellig vægt: nogle er mere urørlige og uforanderlige end andre. De mest abstrakte er de 'tungeste', de i sidste instans hellige postulater ('Ultimate Sacred Postulates" - i en vis jargon, der allerede har dannet sig, hedder de derfor "USP'erne"), fx at "Jahve er én”, at "Gud er en treenig gud...”, at "der er kun én Gud og Muhammed er hans profet”. USP'er er i princippet uforståelige, dvs. de har ingen 
empirisk realitet. De kan derfor ikke verificeres; af samme grund kan de heller ikke falsificeres; de er altså uantastelige i forhold til kendsgerninger. Endelig er det ikke givet, hvilke konsekvenser der følger af accepten af dem. Mere konkrete og mindre tunge er et sæt af kosmologiske aksiomer, der afledes af USP'er; endnu mere konkrete og endnu lettere er bestemte handlingsnormer, der afledes af USP'erne og de kosmologiske aksiomer. Pointen er altså, at jo mere konkrete, desto mere foranderlige. For at give et hjemmelavet og lettere parodierende eksempel: folkekirkelig kirkekaffe kan afledes af treenighedslæren, hvis man sætter, at Gud er treenig og har vist sig for mennesker og bevirket deres forløsning fra synd og død (USP). Deraf følger (kosmologiske aksiomer) bl.a., at verden rummer mennesker, der er skabt af Gud af jord, og som kommer i dødsriget eller bliver til jord igen, men at de skal opstå på den yderste dag og optages i en guddommelig sfære, samt at der er særlige steder, hvor mennesker, der deler denne tro, kan samles og opnå en særlig erfaring eller indsigt $i$ vigtige betydninger. Heraf følger på sin side (som en relativt vægtig handlingsnorm), at menneskene bør tilbede Gud på disse steder; hvoraf følger (som en mindre vægtig handlingsnorm), at menneskene bagefter kan samles omkring kaffe, hvoraf evt. følger (som en lidet vægtig handlingsnorm), at præstens mand laver kaffen. Man kan altså give køb på det mindre vægtige eller lave det om - man kan droppe kirkekaffen, eller lave den om til kaffe, the og vand - uden at ændre på de højere niveauer. Man kan opgive kirkegang og fastholde de øvre niveauer, og man kan endog opgive de kosmologiske aksiomer og stadig fastholde USP'erne.

\section{Adaption}

Dette værdihierarki er adaptivt fordelagtigt, dvs. fordelagtigt for at en religion eller et andet general-purpose system kan fortsætte med at eksistere i et forandret rum. Handlingsnormerne kan møde modstand fra 'verden', når den kontekst, i forhold til hvilken normerne oprindeligt har skullet fungere, ændrer sig; hvis handlingsnormerne har en mere underordnet status, kan kosmologien eventuelt bevares, selv om normerne justeres. Verden kan også gøre modstand, når en ny og anderledes kosmologi virker mere overbevisende end den religiøst-rituelt legitimerede; i så fald er det en adaptiv fordel, hvis de ultimative postulater ikke er bundet alt for tæt op på de kosmologiske aksiomer.

'Adaption' og general-purpose_systems vs special-purpose systems er begreber fra den neo-darwinistiske og batesonske kybernetik, som har haft afgørende indflydelse på Rappaports tankegang. Emblemet $i$ hans bog på denne teoridimension er stamfaderen til landhvirveldyr, kvastfinnen fra Devontiden, en fiskeart, der ifølge zoologen Alfred S. Romers lov ("Romer's Rule"), besvarede periodisk udtørring af de vandhuller, arten levede $\mathrm{i}$, ved evolutionært at transformere finner til ben, så den over landjorden kunne bevæge sig hen til et nyt vandhul. Den forvandlede med andre ord et subsystem (bugens finner) for at bevare sit overordnede system (kroppen som helhed). Pointen er selvfølgelig, at når et system forvandler dele af sig selv, for at resten kan forblive, som det hele tiden har været, som fisken, der forvandler sig til padde 'for at' forblive fisk, forvandles hele systemet ikke desto mindre. Dette er et evolutionært-kybernetisk princip, der kan 
appliceres på alle systemer. Bevares folkekirken således identisk med sig selv, når den 'forvandler' mange af sine præster fra mænd til kvinder?

Det kybernetisk-neo-darwinistiske ses også i den generelle betragtning, at mens subsystemer som kvastfinnens lemmer har et konkret formål (at bevæge resten af kroppen), har det omfattende system ( $\mathrm{fx}$ 'hele kvastfinnen', eller folkekirken, eller det danske samfund, eller menneskeheden) ikke noget andet, overordnet mål end at forblive identisk med sig selv. Det er meget muligt, at systemet som sådan (kvastfinnen, folkekirken, et givet naturligt sprog, et autoværksted, et religionsvidenskabeligt institut, eller hvad som helst ellers, der kan betragtes som et 'system') har en funktion i forhold til et mere overordnet system - Rappaport mener jo netop, at en religion har en sådan funktion, og i den forstand er hans teori klassisk funktionalistisk; men set fra systemets eget synspunkt er det ikke denne funktion, der 'driver det'. Det er blot kampen for at overleve, at forblive, som det hedder, "in the existential game". Omgivelserne, konteksten, hvori et system kan have funktion, giver det mulighed for at overleve. Konteksten kan legitimere systemets eksistens, men begrunder det ikke set inde fra systemet. Det er godt tilfreds med at være, hvad det er (en kvastfinne, en folkekirke, et autoværksted osv.), dvs. det vil selv tendentielt være konservativt, forblive identisk med sig selv (og, kan man måske tilføje, men her ud over hvad Rappaport eksplicit hævder, at vokse, henholdsvis at reduplicere sig selv i så nøjagtige kopier som muligt ...).

\section{Performativitet}

Det afgørende i forbindelse med religiøse systemer er, for en generel og teoretisk synsvinkel som Rappaports, i princippet ikke, hvilke USP'er, der gælder, hvilke kosmologiske aksiomer, der afledes af dem, hvilke konkrete normer, der følger (selv om nogle givetvis er mere adaptivt korrekte end andre, og nogle tangerer det logisk nødvendige, som det fx indirekte fremgår af dekalogens sociale bud, der jo næppe kan tænkes anderledes), men at der overhovedet er USP'er, kosmologiske principper osv. Det er dem, der sikrer en menneskegruppe det minimum af ubetvivlelig og indiskutabel konsensus, som er forudsætningen for, at en gruppe overhovedet kan fungere, at menneskene overhovedet kan leve sammen. Det afgørende er derfor, at deltageren deltager i ritualet. Dermed underkaster deltageren sig de betydninger, der formuleres i det, dets USP'er, dets kosmologiske aksiomer og adfærdsnormer, der fremsiges, bekræftes og indskærpes. Deltagelse betyder ikke nødvendigvis, at deltageren faktisk bliver overbevist om bestemte betydninger eller faktisk agter at følge visse normer for handling og adfærd. Det afgørende er, at deltageren ved sin deltagelse offentligt underkaster sig en forpligtelse til at acceptere disse betydninger og følge disse normer. Ritualdeltagelse er dermed en performativ handling: lige som der ved afgivelse af et løfte etableres en forpligtelse, der gælder for en vis fremtid, etableres der ved ritualdeltagerens blotte deltagelse i ritualet et faktum, som er praktisk ubetvivleligt, nemlig deltagerens underkastelse under en forpligtelse i forhold til gruppens hellige principper osv. Og dette, at der er normer og forpligtelser, og at individerne er forpligtede på dem, uanset om de overholder dem eller ej, eller i hvilken grad de overholder dem, er al samfundsmæssigheds forudsætning. 
Selve ritualets form signalerer og bekræfter den ubetvivlelighed, som USP'erne er omgivet med. Ved ikke at være (fuldstændigt) kodificeret af deltagerne er ritualet selv en ubetvivlelig størrelse, tendentielt evig (eller meget gammel), uforanderlig fra generation til generation - lige som den lære er, der eventuelt sprogligt formuleres som en del af ritualet (dets 'kanoniske meddelelse' - i folkekirken således Bibellæsninger, trosbekendelse osv.), en lære, under hvilken deltagerne underkaster sig, og som de lader gå ind og delvis også ud af deres krop som ved salmesang og eventuel fremsigelse af trosbekendelsen. Ritualets gentagelse modvirker den nedslidning af de fælles værdier, der uundgåeligt vederfares dem i det daglige liv, udsat som de er for alle mulige empiriske fakta, individuelle oplevelser og erfaringer osv., som umiddelbart kan synes at dementere dem. Her, som på mange andre steder, lægger Rappaport sig i umiddelbar og tydelig forlængelse af Durkheim.

Som tegn betragtet er de kanoniske meddelelser rent symbolske (i ovennævnte betydning af arbitrære tegn), og for så vidt kan de formuleres frit i og uden for et ritual. I ritualet suppleres de imidlertid med indeksikale tegn, dvs. tegn, der står i et naturligt og umiddelbart forhold til det, de betegner. Fx er det at knæle, at folde hænderne, at spise brød og drikke vin ikke blot symbolske (og altså arbitrære) tegn på ritualdeltagerens accept af de symbolske betydninger, men tillige indekser, dvs. tegn som er en del af det, de betegner. Man symboliserer ikke blot vilkårligt, at man tilbeder, eller at man er en from person, hvis man står med foldede hænder, men man tilbeder også rent faktisk, man er en from person (ligesom det at knæle eller folde hænderne formentlig er uvilkårlige 'tegn', 'naturlige tegn', dvs. ikke eller ikke fuldt ud kulturbestemte og vilkårlige).

\section{En postmoderne religion}

Rappaports bog minder på mange punkter om Durkheims store Les formes élémentaires de la vie religieuse, og det er ikke kun som en retorisk morsomhed, at Durkheim af Rappaport selv som "Sankt Emil” sættes på linje med den hellige Augustin, eller at det første ord i Keith Harts forord til bogen er "Durkheim”. Begge bøger vil være en religionsteori (og dermed både, beskedent, en ritualteori og, ubeskedent, en kultur- og samfundsteori), der analyserer religionen i dens 'elementære', dvs. dens grundlæggende, bestanddele. Begge udpeger det, en menneskegruppe gør, som det væsentlige, mere end det, gruppen (eller snarere dets enkelte deltagere hver for sig) tror, dvs. begge lægger sig på linje med Robertson Smith. Begge etablerer et spændingsfelt mellem en teoretisk diskurs og "et velgennemført eksperiment" (som Durkheim sagde), dvs. et velbelyst og komplekst etnografisk eksempel (Arrente og andre centralaustralske stammer hos Durkheim, Maring fra Papua-Ny Guinea hos Rappaport). Begge forstår religion som mere eller mindre identisk med et samfunds moral og idealer overhovedet; de er derfor begge 'religionsapologetiske' snarere end 'religionskritiske', selv om selve termen religionsapologetik her vil tangere det meningsløse - kan man være 'for eller imod' kultur og samfundsmæssighed? Heller ikke Rappaports bog kan være den "machine de guerre" imod religion, som Durkheim så udtrykkeligt ikke ville have sin bog til at være, eftersom religion ifølge hans betragtning er moral og idealer, og menneskelig samfunds- 
mæssighed og dermed menneskelighed overhovedet er utænkelig uden moral og idealer. Spørgsmålet for Durkheim var derfor ikke, om moderniteten kan opretholdes uden religion, men om ved hvilken type religion, moderniteten kan opretholdes.

Også Sankt Roy slutter derfor sin store bog af med et kapitel om religion og det moderne, hvor prisen for sekulariseringen betragtes som en moralsk svækkelse, der frembringer spørgsmålet om 'nye guder' på modernitetens præmisser. Durkheim lod det blive ved spørgsmålet, mens Rappaport er mere konkret. Over for økonomien som en generel tænkning, der kun kan fatte individer som konkurrerende enheder, der søger deres eget formål, og over for astronomien som positivistisk modelvidenskab med dens himmellegemer, der forbliver ret uforstyrrede af eventuelle menneskelige betragtere, foreslår han at sætte økologien som modelvidenskab og økologiske principper som et nyt sæt USP'er for den moderne verden. Dyrkelsen af den nye gudinde Gaia og hendes elsker Øko vil da postulere, at menneskets har sin plads i et universelt omfattende system af materialitet og livsformer, og deraf kan afledes menneskets pligt til og egeninteresse $i$ at drage omsorg for dette systems opretholdelse. Dette er ikke et rent irrationelt og arbitrært postulat; men det er samtidig langt fra at være en verificerbar kendsgerning, og det har lige så meget del i religiøse som i videnskabelige principper.

Denne konklusion er passende for et posthumt værk. Den er også passende for et værk, der vil forbinde den antropologiske feltarbejders typiske sympati for det arkaiske med avanceret amerikansk human- og social-videnskabelig forskning og med religionsvidenskabens klassikere. Bogen er selv en virtuel klassiker. Man må håbe, at dens tyngde ikke vil tale imod den, og at den også reelt vil indgå i religionsvidenskabens fortsatte udvikling. Det ville ikke være nogen dårlig ide, hvis nogen satte sig for at omsætte den til en kortere, mere tilgængelig fremstilling. Idé til projekt: "Indføring i Roy Rappaports religionsteori. Omfang: ca. 200 sider".

\section{Litteratur}

BURKERT, WALTER

1996 Creation of the Sacred. Tracks of Biology in Early Religions, Cambridge, Massachusetts.

RAPPAPORT, ROY A.

1979 Ecology, Meaning, and Religion, Richmond.

1984 Pigs for the Ancestors: Ritual in the ecology of a New Guinea people, New Haven.

1999 Ritual and Religion in the Making of Humanity, Cambridge.

Hans J. Lundager Jensen Lektor, mag.art. et dr.theol. Afdeling for Religionsvidenskab Aarhus Universitet 